\title{
Studies on Outsourcing Industry Development in the City of Tongxiang
}

\author{
Yao Yao \\ Hangzhou Institute of Service Engineering, Hangzhou Normal University, Hangzhou, 310012, China \\ yyaoexist@163.com
}

Keywords: Outsourcing Industry; SWOT Analysis; Strategy; The City of Tongxiang

\begin{abstract}
This paper studies the development of outsourcing industry in Tongxiang City. The outsourcing industry development is an important component of the industry transformation and update. This paper analyzes the strengths, weaknesses, opportunities and threats in promoting outsourcing industry in Tongxiang City. With geographical strength and cost strengths, Tongxiang City can seize the opportunity to promote outsourcing. However, with weakness in human resources and relatively weak industry base, Tongxiang City also faces the threats of intense competition. On the basis of SWOT analysis, three strategies are brought up to promote the outsourcing industry in Tongxiang City.
\end{abstract}

\section{Introduction}

The outsourcing industry has been developing rapidly over the past several decades. It started to be an important business management strategy for large international corporations in developing countries as a cost-effective tool since 1980s, and growing fast all over the world ever since. In the post international financial crisis era, the development of outsourcing industry is more and more important in macroeconomic growth in China. For growing labor cost and appreciating domestic currency, the profit margin of exportation of manufacturing goods is decreasing. The issue of college graduate employment is extremely urgent. Structural reform and environmental problems also calls for industry transformation and update, that is, to transfer from low value-added manufacturing to higher value-added industries. Promoting outsourcing industry in China, to transfer the nation from "world factory" into "world office", is one of the important components in macroeconomic growth and structural reform. Tongxiang City, as an important manufacturing town in Zhejiang province, has the necessity and opportunity to promote outsourcing industry. The paper is structured as follows: firstly give the background of outsourcing industry development; and then analyze the strengths, weaknesses, opportunities and threats in the outsourcing industry development in Tongxiang City through SWOT analysis; then analyze strategies to promote outsourcing industry; finally, give some conclusions and policy implications.

\section{SWOT Analysis of Outsourcing Industry in Tongxiang City}

Strengths. One of the strengths to promote outsourcing in Tongxiang City is its unique geographical strength. Tongxiang City is situated in the center of Hangjiahu Plain, which has a convenient transport. The distance between Tongxiang City and important financial and economic centers, such as Shanghai, Hangzhou and Suzhou, is relatively short. It can make full use of the radiant effect of these cities. As an international financial center, Shanghai can provide enough financial outsourcing business to Tongxiang City, both sub-contract of offshore financial outsourcing business and the outsourcing from financial institutions in the city with the largest financial industry in the nation. Service industry has been well developed in Hangzhou and Suzhou, could provide business process outsourcing to Tongxiang City. New high-technological enterprises cluster in Hangzhou, which could provide IT outsourcing business to Tongxiang City. The relatively low cost is another strength in Tongxiang City. 
The cost of human resources is an important factor in the outsourcing industry, which was originated as a business strategy to reduce labor costs in higher developed countries or regions. The much lower labor cost in Tongxiang City could attract outsourcing business. The rental cost, electronic communication cost and utility cost are also lower in Tongxiang City. International corporations that outsourced their business to the Southeastern China are confronted by the rising costs. One way to solve the cost problem is to move their outsourcing business to other parts of the nation, such as western regions of China, or to other lower cost nations, such as Thailand or India. However, the reallocation is also costly, and culture shock could be a problem. Transfer outsourcing business form large cities in southeastern China to Tongxiang City, could enjoy the low cost as well as a business friendly environment.

Weaknesses. The underdevelopment of service industry in Tongxiang City is one of the impediments in promoting the outsourcing industry. The pillar industry in Tongxiang City remains to be conventional manufacturing, being especially concentrated in textile industry. The recently developed third industry concentrates on commercial trade business and traveling. The development of service industry in Tongxiang City falls far behind neighboring cities. High technological corporation is rare in Tongxiang City. Without a sound service industry base, the development of outsourcing business can be difficult. Another weakness is human resources. Owing to lack of professionals and expert in the outsourcing industry, as well as shortage of managerial and technological employees, Tongxiang City has difficulty weakness in attracting the outsourcing business. Human resource is a prevailing problem in the outsourcing industry. As a new service industry, outsourcing has specific requirements in human resources, which is the most important factor. There is no university in Tongxiang City. Local junior colleges in Tongxiang focus on teaching training, which do not have the ability to provide training for the outsourcing industry. As a manufacturing city, Tongxiang City is unable to provide job opportunities for college graduates. Over the years, Tongxiang City failed to attract local students who went to college.

Opportunities. After the global financial crisis, from the enterprises of developed countries use the cost reduction as a risk management method, which means more opportunities for developing countries. Globalization and overseas operation become more and more important in development strategy for large corporations in the US and Europe. Service outsourcing, especially IT outsourcing, has been developing ever faster than before the crisis. The global financial crisis is also an opportunity for emerging economy to conduct the structural reform, so as to transfer from high pollution, high energy consuming and low value added manufacturing sector to higher value added and lower environment cost service industry. The outsourcing industry is supported by national industry policy. The support industrial policies provide a good policy environment and create the development space for outsourcing industry. Policies in human resources, tax, financing and other aspects facilitate the development of outsourcing industry. The issue of employment, especially for college graduates, becomes an important social matter. By promoting outsourcing industry, attracting offshore outsourcing business from large overseas corporations, can provide college students more job opportunities, improves not only employment quantity but also quality. College students have sufficient ability and knowledge, with proper training, can be qualified employee in the outsourcing industry.Tongxiang City is literally surrounded by outsourcing centers, such as the city of Hangzhou, Wuxi and Suzhou. Seizing the opportunity of subcontracts from the cities can be a good start to promote outsourcing industry in Tongxiang City.

The threats. Lack of industry cluster and brand effect, is a major challenge for Tongxiang City to promote outsourcing industry. As a small city featured with textile industry, Tongxiang City may have difficulty attracting outsourcing business in the first place. Large international corporations which outsourced their business never even heard of the city, much less likely to seek business in the city. The short distance to Shanghai, can also be a two edged sword in developing outsourcing industry. Tongxiang City may attract some corporations by preferential policy. However, these corporations may 
enjoy lower cost, tax deduction, city subsidy and other policy dividend from Tongxiang City, while actually growing business in the nearby city of Shanghai. Tongxiang City would face intense competitions, with competitors from domestic market and overseas. Many cities started to make outsourcing industry as special-supported, strategic important industry. Similar preferential policy is carried out all over the country. International competition is also intense. Chinese outsourcing companies need to compete with India, Thailand, Philippines, Ireland, with the background of appreciating currency, rising labor cost and rental cost. India has a longer history and much more experience in the outsourcing industry, and less language barrier. Thailand and Philippines started outsourcing business more recently than China, but with much lower costs, they have already become favorable destiny for outsourcing business. Ireland has its cultural and geographical strengths in outsourcing business. In post financial crisis era, uncertainties are still clouding global economy. Many multinational corporations delayed their plan in offshore outsourcing, especially high-end outsourcing, contracts with large amount and longer term contracts.

\section{Development strategy of outsourcing industry in Tongxiang}

Location strategy. Economic location indicates economic growth point and its radiation scale are an geographical and economic concept. Economic location is where capital, technology and other economic factors cluster. The formation of economic location can brought forward the macroeconomic growth in the nearby region. Tongxiang City could make full used of the location strengths of the delta of Yangtze River, attracting capital, technology and other economic factors from the radiation of Shanghai, Hangzhou and Suzhou.

Human Resources Strategy. Tongxiang City, as a manufacturing town, needs to adopt modern human capital management ideas to attract and cultivate the human resources. With opportunities of training, cultivation creativity, team building, motivation and sharing, creative performance evaluation and salary distribution system, Tongxiang City can provide outsourcing industry a high quality human resource group. Enhancing cooperation between education institutions and the industry, especially cooperation between universities and outsourcing service companies, is one way to fill the gap of human resource shortage in the outsourcing industry. Make full use of the geographical strength, attracting college students from the Xiasha campus nearby which accommodate many universities.

Industrial Strategy. When promoting outsourcing industry in Tongxiang City, which has relatively weak industry base, business process outsourcing can be a good start. Business process outsourcing handles repetitive and non core business process, which aims at lower cost and better service quality. Typical business process outsourcing includes customer management, calling center, technical support and back office service. Business process outsourcing has relatively lower requirements in technology and human resources, is within the reach of the ability of the city. Local college students majored in foreign language or business studies can be qualified staff in business process outsourcing industry. After the development of several business process outsourcing companies, Tongxiang City can started outsourcing in the field with higher technology requirements. Cultivate some high technology corporations which can process information technology outsourcing would be the next step. Information technology outsourcing is the largest sector in the outsourcing industry. To outsource IT system and other IT related business, so that the corporation can focus on its core business, is becoming prevail business behavior in recent two decades. The demand of information technology outsourcing is increasing rapidly, which take up more than half of the outsourcing business in China. Tongxiang City can attract information technology companies from other cities by preferential policies, so as to help cultivating local high technology companies. With outside help from the well developed companies from other cities, Tongxiang City can form an industry cluster, and make up for the weakness in technology. 


\section{Conclusions}

The development of outsourcing industry is an important component of economic structural reform. The outsourcing industry is supported by the industry transformation and update. Tongxiang City is a town focuses on traditional manufacturing in Zhejiang Province. This paper analyzed the strengths, weaknesses, opportunities and threats in promoting outsourcing industry in Tongxiang City. With geographical strength and cost strengths, Tongxiang City can seize the opportunity to promote outsourcing. However, with weakness in human resources and relatively weak industry base, Tongxiang City also facing threats in intense competition. On the basis of SWOT analysis, three strategies are brought up to promote the development of outsourcing industry in Tongxiang City, which are location strategy, human resources strategy and industrial strategy.

\section{Acknowledgement}

This study is supported by the Natural Science Foundation of Zhejiang Province, Research on financial time series data mining, LQ15F020013.

\section{References}

[1] J. Hätönen, T. Eriksson, 30+ Years of Research and Practice of Outsourcing - Exploring the Past and Anticipating the Future, Journal of International Management, 15 (2009) 142-155

[2] M.C. Lacity, S.A. Khan, L.P. Willcocks, A Review of the IT Outsourcing Literature: Insights for Practice, Journal of Strategic Information Systems, 18 (2009) 130-146

[3] W.L. Tate, L.M. Ellram, L. Bals, E. Hartmann, Offshore Outsourcing of Services: An Evolutionary Perspective, Int. J. Production Economics, 120 (2009) 512-524

[4] A.M.D. Ferreira, F.J.B. Laurindo, Outsourcing Decision-making Aspects Considered by IT Departments in Brazilian Companies, Int. J. Production Economics, 122 (2009) 305-31

[5] A.A. Bush, A. Tiwana, H. Tsuji, An Empirical Investigation of the Drivers of Software Outsourcing Decisions in Japanese Organizations, Information and Software Technology, 50 (2008) 499-510

[6] S. Cai, K. Ci, B. Zou, Producer Services Outsourcing Risk Control Based on Outsourcing Contract Design: Industrial Engineering Perspective, Systems Engineering Procedia, 2 (2011) 308-315

[7] F. K. Alaghehband, S. Rivard, S. Wu, S. Goyette, An Assessment of the Use of Transaction Cost Theory in Information Technology Outsourcing, Journal of Strategic Information Systems, 20 (2011) $125-138$

[8] M. Rekik, K. Boukadi, H. Ben-Abdallah, A Decision-making Method for Business Process Outsourcing to the Cloud based on Business Motivation Model and AHP, International Journal of Cloud Computing, 4 (2015) 47-62.

[9] Information on http://www.jxstats.gov.cn/

[10] Information on http://www.zj.stats.gov.cn/ 